\title{
Levels of neutral detergent fiber in diets with forage palm for dairy goats
}

[Fibra em detergente neutro em dietas com palma forrageira para cabras leiteiras]

\author{
N.M. Sousa ${ }^{1}$, J.S. Oliveira ${ }^{1}$, D.S. Silva ${ }^{1}$, E.M. Santos ${ }^{1}$, A.N. Medeiros ${ }^{1}$, \\ J.P.F. Ramos ${ }^{2 *}$, E.A. Brito ${ }^{2}$ \\ ${ }^{1}$ Universidade Federal da Paraíba - Areia, PB \\ ${ }^{2}$ Empresa Estadual de Pesquisa Agropecuária da Paraíba S.A - João Pessoa, PB
}

\begin{abstract}
This study aimed to evaluate the amount of fiber in the diet that is able to promote better use of nutrients in the diet of dairy goats when forage palm is the main source of roughage. Fifteen Alpine dairy goats were distributed in a $5 \times 5$ triple Latin square containing five treatments and five periods, and each treatment contained. We tested five diets composed of different contents of neutral detergent fiber from Tifton hay (NDFf) in the dry matter of rations containing forage palm: D1: $11.98 \%$; D2: $18.31 \%$; D3: 23.68\%; D4: $28.76 \%$ and D5: $32.12 \%$ NDFf. The intake of dry matter, crude protein, neutral detergent fiber, non-fiber carbohydrates and ether extract decreased linearly with the increase in NDFf content. There was a linear increase of milk production and milk protein with increasing dietary NDFf. The fat, dry extract, protein, $\mathrm{pH}$ and acidity of the evaluated milk were not affected by increasing the levels of NDFf in the diet. In situations where dairy goats are fed forage palm and other types of forage are limited, $11.98 \%$ NDF from forage other than palm can be used as an effective source of NDF.
\end{abstract}

Keywords: effective fiber, fat, goats, milk, performance

\section{RESUMO}

Objetivou-se, com este trabalho, avaliar a quantidade de fibra na dieta que é capaz de promover melhor uso de nutrientes na dieta de cabras leiteiras quando a palma forrageira é a principal fonte de forragem. Quinze cabras leiteiras alpinas foram distribuídas em um quadrado latino triplo $5 \times 5$ contendo cinco tratamentos e cinco períodos. Testaram-se cinco dietas compostas por diferentes teores de fibra em detergente neutro de feno de tifton (FDNf) na matéria seca de rações contendo palma forrageira: D1: 11,98\%; D2: 18,31\%; D3: 23,68\%; D4: 28,76\% e D5: 32,12\% de FDNf. A ingestão de matéria seca, proteína bruta, fibra em detergente neutro, carboidratos não fibrosos e extrato etéreo diminuiu linearmente com o aumento do conteúdo de FDNf. Houve um aumento linear da produção de leite e da proteína do leite com o aumento da FDNf dietética. A gordura, a lactose, o extrato seco, o pH e a acidez. do leite não foram afetados pelo aumento dos níveis de FDNf na dieta. Em situações em que as cabras leiteiras são alimentadas com palma forrageira e outros tipos de forragem são limitados, 11,98\% de FDN de forragem diferente da palma podem ser usados como fonte efetiva de fibra.

Palavras-chave: fibra efetiva, gordura, cabras, leite, desempenho

\section{INTRODUCTION}

The supply of forage for ruminants in semiarid regions is based on the use of crops adapted to water stress, such as the forage palm, which guarantees the maintenance of animal productivity during the dry season. Forage palm

Recebido em 18 de julho de 2017

Aceito em 16 de dezembro de 2017

* Autor para correspondência (corresponding author)

E-mail: jpemepapb@yahoo.com.br has neutral detergent fiber (NDF) values of approximately $20 \%$ dry matter (DM) and significant levels of calcium, potassium, magnesium and oxalates. However, it appears that ruminants that eat it as the only roughage present weight loss and diarrhea (Wanderley et al., 2002). The addition of other roughages in diets containing forage palm can improve animal health and performance (Wanderley et al., 2002). 
The presence of oxalate in the palm has been considered as a diarrheal cause in ruminants. However, forage palm has around $0.16 \%$ of oxalate based in dry matter, very below the level that is necessary to cause toxicity, which is $2 \%$ of dry matter (Batista et al., 2009). Therefore, other reasons need to be need investigated.

Ruminants require a minimum amount of fiber in the diet to maintain adequate ruminal fermentation and, consequently, animal health. It is necessary that part of this fiber should come from forage, because neutral detergent fiber from forage (NDFf) stimulates the chewing activity and saliva production, which maintain the buffering capacity of rumen (Nutrient..., 2001). Various parameters have been used to monitor ruminal conditions including milk fat percentage (Nutrient..., 2001). Effective fiber is the amount of fiber in the diet that maintains the percentage of fat in the milk (Nutrient..., 2001).

Based on numerous studies with cows fed diets containing alfalfa and concentrate, it was found that diets with $25 \% \mathrm{NDF}, 19 \%$ NDFf and $44 \%$ non-fiber carbohydrates (NFC) result in production and composition similar to the milk of cows fed high NDF concentrations (Mertens, 1997). In balancing rations for goats (mainly dairy goats), these studies are used to recommend the minimum amount of NDF in the ration.

In diets that contain forage palm as the main ingredient, it was found that palm does not contain sufficient NDF to be effective in maintaining animal performance and good rumen health (Ferreira et al., 2010). One way to overcome this problem is the inclusion of other sources of NDF in the diet (Ferreira et al., 2010). However, it is uncertain how much more NDF from other sources of forage is necessary to maintain animal performance (Ferreira et al., 2010 and Wanderley et al., 2002).

Thus, the objective of this study was to evaluate the amount of fiber in the diet that is able to promote better use of nutrients in the diet of dairy goats when forage palm is the main source of roughage.

\section{MATERIAL AND METHODS}

The experiment was conducted from May to August 2012 at the Estação Experimental
Pendência, which belongs to the EMEPA-PB, Empresa Estadual de Pesquisa Agropecuária da Paraíba, located in the rural area of Paraíba, micro-region of West Curimataú, municipality of Soledade - PB, Brazil ( $7^{\circ} 8$ ' $18^{\prime \prime} \mathrm{S}$ and $36^{\circ} 27^{\prime} 2^{\prime \prime}$ W), with an altitude of $534 \mathrm{~m}$. The bromathological analyses were performed at the Laboratory of Animal Nutrition, Department of Animal Science, Federal University of Paraíba (UFPB), located in Areia-PB, Brazil.

Fifteen multiparous alpine dairy goats with a mean body weight (BW) of $43.09 \pm 1.94 \mathrm{~kg}$, at \pm 30 days in milk at the start of the study, were used. The experimental design used was a triple Latin square $(5 \times 5)$, with five treatments and five periods, balanced in accordance with the lactation period and milk production of the goats. Each animal was housed in an individual "tie" type stall and provided with a feeder and drinker, where they received their diet. The experiment was approved by the Committee of Ethics in the Animal Using - CEUA - CBiotec of the Federal University of Paraíba (UFPB), with protocol number: CEUA N ${ }^{\circ} 2105 / 13$.

The diets consisted of forage palm, Tifton hay, and concentrate supplement, and the treatments represented diets with different levels of NDF from Tifton hay (NDFf) in the dry matter: D1: 11.98\%; D2: 18.31\%; D3: 23.68\%; D4: $28.76 \%$ and D5: $32.12 \%$ NDFf. The Tifton hay used in the present study was obtained from a local commercial farm. Bales of hay were chopped in a stationary tub grinder to a geometric mean particle length of $20.0 \mathrm{~mm}$.

The diets were formulated to be isonitrogenous and to meet the requirements of the NRC (2007) for goats weighing on average $45 \mathrm{~kg}$ and producing $2.5 \mathrm{~kg}$ of milk per day with $4.0 \%$ fat (Table 1) and (Table 2).

The experiment consisted of five periods lasting 21 days each, with 14 initial days for diet adaptation and the rest for data collection. The animals were confined and fed twice per day (8:00 a.m. and 3:30 p.m.) in equal proportion, and the food was supplied individually as total mixed rations. The diets were provided ad libitum, so that there were at least $10 \%$ leftovers, which were weighed daily so that the food supply level was properly adjusted. 
Table 1. Chemical composition of the ingredients contained in experimental feeds based on dry matter

\begin{tabular}{ccccc}
\hline Item & \multicolumn{3}{c}{ Ingredients $^{1}\left({\left.\mathrm{~g} . ~ \mathrm{~kg}^{-1} \mathrm{DM}\right)}^{2}\right.$} \\
\cline { 2 - 5 } & $\begin{array}{c}\text { Forage } \\
\text { Palm }\end{array}$ & Tifton hay & Corn grain & $\begin{array}{c}\text { Soybean } \\
\text { meal }\end{array}$ \\
\hline Dry matter $^{1}$ & 93.5 & 829.2 & 816.9 & 813.6 \\
Crude protein $_{\text {Ether extract }}$ & 57.6 & 93.4 & 83.6 & 524.9 \\
Neutral detergent fiber $^{2}$ & 21.2 & 21.1 & 44.4 & 26.2 \\
Acid detergent fiber $^{2}$ & 339.4 & 750.7 & 162.3 & 253.7 \\
Lignin (sa) $^{3}$ & 226.8 & 380.4 & 49.6 & 121.8 \\
Cellulose $_{\text {Hemicellulose }}$ & 34.0 & 51.4 & 11.6 & 13.3 \\
Non-fibrous carbohydrate $_{\text {Ash }}$ & 192.8 & 329.0 & 38.0 & 108.5 \\
& 112.6 & 370.3 & 112.7 & 131.9 \\
\hline
\end{tabular}

$\% \mathrm{~g} \mathrm{~kg}^{-1}$ based on the natural matter; ${ }^{2}$ Exempt of ashes and protein and assayed with a heat stable amylase; ${ }^{3}$ lignin determined by solubilization off cellulose with sulphuric acid.

Table 2. Chemical composition of the experimental diets

\begin{tabular}{|c|c|c|c|c|c|}
\hline \multirow{3}{*}{ Item } & \multicolumn{5}{|c|}{ Diets $^{1}$} \\
\hline & $11.98 \%$ & $18.31 \%$ & $23.68 \%$ & $28.76 \%$ & $32.12 \%$ \\
\hline & \multicolumn{5}{|c|}{ Proportions of ingredients (g. $\left.\mathrm{kg}^{-1} \mathrm{DM}\right)$} \\
\hline Forage palm & 420.6 & 350.2 & 291.1 & 235.9 & 199.0 \\
\hline Tifton hay & 159.6 & 244.0 & 315.5 & 383.2 & 427.8 \\
\hline Sobyeal meal & 135.5 & 129.1 & 126.0 & 122.3 & 120.0 \\
\hline Corn grain & 263.5 & 254.1 & 245.9 & 238.6 & 233.7 \\
\hline Urea & 10.4 & 10.4 & 9.5 & 8.6 & 8.4 \\
\hline \multirow[t]{2}{*}{ Mineral $\operatorname{mix}^{2}$} & 10.4 & 12.2 & 11.9 & 11.4 & 11.2 \\
\hline & \multicolumn{5}{|c|}{ Chemical composition (g. $\left.\mathrm{kg}^{-1} \mathrm{DM}\right)$} \\
\hline $\mathrm{NDFf}^{3}$ & 119.8 & 183.1 & 236.8 & 287.6 & 321.2 \\
\hline Dry matter ${ }^{4}$ & 192.2 & 220.6 & 251.8 & 290.0 & 322.7 \\
\hline Crude protein & 132.3 & 132.0 & 132.9 & 133.5 & 133.9 \\
\hline Ether extract & 27.5 & 27.2 & 27.0 & 26.9 & 26.7 \\
\hline aNDFom $^{5}$ & 313.4 & 347.2 & 376.5 & 404.4 & 422.6 \\
\hline Ash & 83.7 & 76.3 & 68.3 & 60.7 & 55.7 \\
\hline $\mathrm{NFC}^{6}$ & 482.7 & 456.9 & 434.9 & 414.1 & 400.7 \\
\hline
\end{tabular}

${ }_{1}^{1} 11,98 \%=11,98 \%$ of neutral detergent fiber from Tifton hay; $18,31 \%=18,31 \%$ of neutral detergent fiber from tifton hay; $23,68 \%=23,68 \%$ of neutral detergent fiber from Tifton hay; $28,76 \%=28,76 \%$ of neutral detergent fiber from tifton hay; $32,12 \%=32,12 \%$ of neutral detergent fiber from Tifton hay. ${ }^{2}$ Mineral mix (nutrient $/ \mathrm{kg}$ of supplement): vitamin A 135.000,00I.U..; Vitamin D3 68.000,00I.U.; vitamin E 450,00I.U.; calcium 240g; phosphorus 71g; potassium 28,2g; sulfur 20g; magnesium 20g; copper $400 \mathrm{mg}$; cobalt $30 \mathrm{mg}$; chromium $10 \mathrm{mg}$; iron $2500 \mathrm{mg}$; iodine 40mg; manganese 1350mg; selenium 15mg; zinc 1700mg; maximum fluorine $710 \mathrm{mg}$; phosphorus (P) solubility in $2 \%$ citric acid (min.). ${ }^{3}$ Neutral detergent fiber from Tifton hay; ${ }^{4} \%$ based on the natural matter; ${ }^{5}$ Neutral detergent fiber exempt of ashes and protein and assayed with a heat stable amylase; ${ }^{6}$ Non-fibrous carbohydrate.

Samples of the supplied food and the leftovers were collected during the seven days of collection and then weighed. Composite samples were made of the samples for each trial period to determine the digestible dry matter content, digestible organic matter, digestible crude protein, digestible ether extract, digestible nonfiber carbohydrates and digestible neutral detergent fiber. The analyses followed the conditions described in the AOAC (Official...,
1998), except for the neutral detergent fiber (aNDFom). The aNDFom contents were estimated according to Mertens' recommendations (2002) and with corrections regarding ash and protein contents in the aNDFom as recommended by Mertens (2002) and Licitra et al. (1996).

The feces were collected in the final portion of the rectum on the 16th day (6:00 a.m.), 17th day 
(9:00 a.m.), 18th day (12:00 p.m.), 19th day (3:00 pm) and 20th day (6:00 p.m.). The amount of fecal dry matter excreted, used to determine the apparent digestibility of the food and the total digestible nutrients (TDN), was estimated by the concentration of indigestible neutral detergent fiber (iNDF) obtained after in situ incubation of the foods, leftovers and feces over a period of 244 hours in a fistulized bovine (Casali, 2006). Apparent digestibility was calculated according to Berchielli et al. (2011).

The energy value of the diets (TDN) was obtained through data from the apparent digestibility observed in the experiment and calculated according to Sniffen et al. (1992):

$\mathrm{TDN}=($ ingested $\mathrm{CP}-$ fecal $\mathrm{CP})+2.25 *$ (ingested EE - fecal EE) + (ingested NDF - fecal $\mathrm{NDF})+($ ingested NFC - fecal NFC);

$\%$ TDN $=(\mathrm{TDN}$ Consumption $/ \mathrm{DM}$ Consumption) $* 100$

The conversion of the TDN values of the diets for digestible energy (DE) and metabolizable energy (ME) was performed using equations described by the NRC (Nutrient..., 2001):

DE (Mcal. Kg-1) $=0.04409 *$ TDN (\%); ME $(\mathrm{Mcal} . \mathrm{Kg}-1)=1.01 * \mathrm{DE}(\mathrm{Mcal} / \mathrm{kg})-0.45$

Milk production was measured daily, and the average of the last seven days of each animal within each period was used for statistical analysis. Composite milk samples were collected in the morning milking $(120 \mathrm{~mL})$ and afternoon milking $(80 \mathrm{~mL})$ to determine the milk composition ( $\mathrm{pH}$, density, moisture, lactose content, dry extract, protein, and fat) of each animal within each period. The milking and handling procedures followed the recommendations of the Technical Regulation of Production, Identity and Quality of goat milk (Brasil, 2000).

In the physico-chemical analysis of the milk, the total nitrogen (TN) contents were determined, and the protein content was then calculated as $\mathrm{CP}$ $=\mathrm{TN} \times 6.38$ using the micro-Kjeldahl method (AOAC 991.20 and 991.23 methods) (Official..., 1998); total dry extract by drying until obtaining constant weight (AOAC 925.23 method) (Official..., 1998); lipids, using a Gerber lactobutyrometer described in the Brasil (Métodos..., 2005); and lactose (g. 100g-1) by
Fehling's solution (Métodos..., 2005). The density index, using a thermolactodensimeter at $15^{\circ} \mathrm{C}$ (Métodos..., 2005), and the acidity, expressed in ${ }^{\circ} \mathrm{D}$ (AOAC 947.05 method) (Official..., 1998), were also determined.

For conversion of the production of $4 \%$ fat, the following formula was used according to NRC (2001):

FCM 4\% (kg.day-1) = 0.4x milk $(\mathrm{kg} \cdot$ day -1$)+15$ $\times$ fat (kg.day-1).

Feed efficiency was determined by dividing the milk production by the dry matter intake.

The ingestion behavior of the animals was determined on the 14th day of each trial period through individual observation of the time spent in feeding, rumination and idleness time over 24 hours. For this purpose, we used the instantaneous scanning method proposed $b$ Martin and Bateson (1986), at intervals of five minutes (Johnson and Combs, 1991). The following variables were observed and recorded: total feeding time (TFT): the period in which the animal grasped the food, chewed, salivated and swallowed the bolus; Total Rumination (TR): the period in which the animal regurgitated, rechewed and swallowed the regurgitated material; and Total Idleness (TI): the period in which the animal did not eat or ruminate.

The following relationships were also calculated, adapted from Bürger et al. (2000): $\mathrm{FE}=\mathrm{DMI} / \mathrm{TFT}(\mathrm{kg} \mathrm{DM} / \mathrm{h})-$ Feeding efficiency due to DM intake;

$$
\mathrm{FE}=\mathrm{NDFI} / \mathrm{TFT}(\mathrm{kg} \mathrm{NDF} / \mathrm{h})-\text { Feeding }
$$

efficiency due to NDF intake;

$\mathrm{RE}=\mathrm{DMI} / \mathrm{TR}(\mathrm{kg} \mathrm{DM} / \mathrm{h})$ - Rumination efficiency due to DM intake;

$\mathrm{RE}=\mathrm{NDF} / \mathrm{TR}(\mathrm{kg} \mathrm{NDF} / \mathrm{h})$ - Rumination efficiency due to NDF intake.

The measurement of water intake was performed through weighing of water twice daily (5:30 a.m. and 3:30 p.m.) between the 15 th and the $21 \mathrm{st}$ days of the experimental period. Water was provided ad libitum, and its consumption was estimated by difference of weight. The daily evaporation rate was estimated by distributing buckets at different parts of the shed, so that the amount of water lost by evaporation could be verified on the next day and thus these losses 
were discounted from the consumption of animals.

The effects of the NDFf levels were evaluated by regression analysis using the determination coefficients and significance of regression parameters as the model choice criteria. These parameters were tested using a t-test at a probability level of 5\%, using the GLM procedure of SAS (Statistical..., 2017). The statistic model was defined as follows:

$\mathrm{Yijkl}=\mu+\mathrm{A}(\mathrm{k}) \mathrm{i}+\mathrm{Pj}+\mathrm{Qk}+\mathrm{Tl}+\mathrm{QTkl}+\xi \mathrm{ijkl}$ where: Yijkl = Observation of animal $\mathrm{i}$ (random effect), in period $\mathrm{j}$ (random effect), on square $\mathrm{k}$ (random effect), subjected to treatment 1 (fixed effect); $\mu=$ overall effect of the mean; $\mathrm{A}(\mathrm{k}) \mathrm{i}=$ effect of animal $\mathrm{i}$ on square $\mathrm{k}$, with $\mathrm{i}=1,2,3,4$, $5 ; \mathrm{Pj}=$ effect of period $\mathrm{j} ; \mathrm{Qk}=$ effect of the Latin square, with $\mathrm{k}=1,2,3 ; \mathrm{Tl}=$ effect of treatment 1 , with $1=1,2,3,4,5$; QTkl = interaction of the effect with the Latin square $\times$ treatment 1 ; and $\xi \mathrm{ijkl}=$ random error associated with each observation Yijkl.

\section{RESULTS}

NDFf showed a decreasing linear effect on the intake of DM, nutrients (NDF, CP, EE, NFC) and $\mathrm{ME}$ (Table 3). Increasing the concentration of NDFf in the diet produced a decrease in DM intake and, therefore, in nutrients and ME. Table 2 shows that, when the concentrations of NDFf in the feeds increased, the aNDFom increased proportionately, which may have negatively affected the dry matter intake.

Table 3. Intakes of chemical components by dairy goats fed neutral detergent fiber from tifton hay levels (FDNf)

\begin{tabular}{|c|c|c|c|c|c|c|c|c|c|}
\hline \multirow[b]{2}{*}{ Parameters $^{2}$} & \multicolumn{6}{|c|}{ Diets $(\%)^{1}$} & \multicolumn{2}{|c|}{ P-Value } & \multirow[t]{2}{*}{ Equations } \\
\hline & 11.98 & 18.31 & 23.68 & 28.76 & 32.12 & SEM & Linear & Quad. $^{3}$ & \\
\hline DMI (kg.day $\left.{ }^{-1}\right)$ & 1.98 & 1.77 & 1.53 & 1.44 & 1.19 & 26 & 001 & 0.879 & $\hat{\mathrm{Y}}=2.15$ \\
\hline & & & & & & & & & $4 x$ \\
\hline DMI $\left(\mathrm{kg} \cdot \mathrm{kg}^{-0.75}\right)$ & 12.72 & 11.43 & 9.83 & 9.14 & 7.55 & 1.65 & .0001 & 0.846 & $\hat{\mathrm{Y}}=15.796-0.246 \mathrm{x}$ \\
\hline NDFI (g.day ${ }^{-1}$ ) & 730.61 & 648.24 & 527.81 & 489.49 & 351.03 & 110.15 & 6.0001 & 0.779 & $\hat{Y}=958.04-17.788 x$ \\
\hline & & 1.58 & 1.27 & 1.16 & 0.8 & & 0001 & & $\hat{\mathrm{Y}}=2 .$. \\
\hline NDFI (kg.kg $\left.{ }^{-0.75}\right)$ & 4.69 & 4.16 & 3.36 & 3.08 & 2.23 & 0 & $<.0001$ & 50 & $\hat{\mathrm{Y}}=6.1$ \\
\hline CPI (g.day $\left.{ }^{-1}\right)$ & 270.85 & 243.42 & 218.19 & 204.36 & 178.02 & 31.17 & $<.0001$ & & $\hat{\mathrm{Y}}=323$ \\
\hline EEI (g.day $\left.{ }^{-1}\right)$ & 56.21 & 50.54 & 45.36 & 41.67 & 35.65 & 6.76 & $<.0001$ & 0.904 & $\hat{\mathrm{Y}}=68.281-0.974 \mathrm{x}$ \\
\hline NFCI (g.day $\left.{ }^{-1}\right)$ & 775.26 & 699.04 & 637.84 & 600.33 & 535.57 & 100.19 & $<.0001$ & 0.633 & $\hat{\mathrm{Y}}=909.84-11.329 \mathrm{x}$ \\
\hline MEI (Mcal.day $\left.{ }^{-1}\right)$ & 5.34 & 4.68 & 4.50 & 4.19 & 3.71 & 0.37 & $<.0001$ & 0.860 & $\hat{Y}=-6.170-0.073 x$ \\
\hline
\end{tabular}

${ }^{1} 11,98=11,98 \%$ of neutral detergent fiber from Tifton hay; $18,31=18,31 \%$ of neutral detergent fiber from Tifton hay; $23,68=23,68 \%$ of neutral detergent fiber from Tifton hay; $28,76=28,76 \%$ of neutral detergent fiber from Tifton hay; $32,12=32,12 \%$ of neutral detergent fiber from Tifton hay; ${ }^{2} \mathrm{DMI}=$ dry matter intake; NDFI= neutral detergent fiber intake; $\mathrm{CPI}=$ crude protein intake; $\mathrm{EEI}=$ ether extract intake; $\mathrm{NFCI}=$ non-fiber carbohydrate intake; $\mathrm{MEI}=$ metabolizable energy intake. $\% \mathrm{BW}=$ Body weight, $\mathrm{kg} / \mathrm{kg}^{0,75}=$ metabolic weight. ${ }^{3}$ Quadratic.

The intake of supplied and total water increased linearly with the increase in the concentration of NDFf in the diet (Table 4), while water intake via the diet showed a decreasing linear effect.
The digestibility of DM and other nutrients showed increasing linear effects with the varying levels of NDFf in the diet (Table 5).

Table 4. Intakes of water by dairy goats fed neutral detergent fiber from tifton hay levels (FDNf)

\begin{tabular}{|c|c|c|c|c|c|c|c|c|c|}
\hline \multirow[b]{2}{*}{ Paramters $^{2}$} & \multicolumn{6}{|c|}{ Diets $(\%)^{1}$} & \multicolumn{2}{|c|}{ P-Value } & \multirow[b]{2}{*}{ Equations } \\
\hline & 11.98 & 18.31 & 23.68 & 28.76 & 32.12 & SEM & Linear & Quad. $^{3}$ & \\
\hline OWI (kg.day $\left.{ }^{-1}\right)$ & 1.74 & 2.32 & 2.78 & 3.40 & 3.57 & 0.79 & $<.0001$ & 0.734 & $\hat{Y}=1.341+0.415 x$ \\
\hline DWI (kg.day $\left.{ }^{-1}\right)$ & 5.03 & 5.21 & 4.69 & 4.91 & 4.88 & 0.88 & $<.0001$ & 0.443 & $\hat{Y}=5.124-0.060 x$ \\
\hline TWI (kg.day $\left.{ }^{-1}\right)$ & 6.77 & 7.53 & 7.48 & 8.31 & 8.46 & 0.79 & $<.0001$ & 0.735 & $\hat{Y}=6.465+0.415 x$ \\
\hline
\end{tabular}

${ }^{1} 11,98=11,98 \%$ of neutral detergent fiber from Tifton hay; $18,31=18,31 \%$ of neutral detergent fiber from Tifton hay; $23,68=23,68 \%$ of neutral detergent fiber from Tifton hay; $28,76=28,76 \%$ of neutral detergent fiber from Tifton hay; $32,12=32,12 \%$ of neutral detergent fiber from Tifton hay; ${ }^{2} \mathrm{OWI}=$ Offered water intake, DWI $=$ diet water Intake, TWI $=$ total water intake. ${ }^{3}$ Quadratic. 
Table 5. Apparent digestibility coefficients of the nutrients and metabolizable energy of the diets in dairy goats fed neutral detergent fiber from Tifton hay levels (FDNf)

\begin{tabular}{|c|c|c|c|c|c|c|c|c|c|}
\hline & \multicolumn{6}{|c|}{ Diets $(\%)^{1}$} & \multicolumn{2}{|c|}{ P-Value } & \\
\hline Parameters $^{2}$ & 11.98 & 18.31 & 23.68 & 28.76 & 32.12 & SEM & Linear & Quad. $^{3}$ & \\
\hline $\mathrm{DM}\left(\mathrm{g} . \mathrm{kg}^{-1}\right)$ & 709.95 & 699.25 & 763.38 & 773.79 & 825.04 & 6.50 & $<.0001$ & 0.271 & $\hat{\mathrm{Y}}=620$ \\
\hline $\mathrm{CP}\left(\mathrm{g} . \mathrm{kg}^{-1}\right)$ & 794.97 & 786. & 8.32 & 844.50 & & 5.08 & 001 & & $378 x$ \\
\hline $\operatorname{NDF}\left(\mathrm{g} . \mathrm{kg}^{-1}\right)$ & 623.32 & 585.19 & 648.09 & 653.69 & 693 & 7.89 & 02 & 0.202 & $898 x$ \\
\hline $\mathrm{EE}\left(\mathrm{g} . \mathrm{kg}^{-1}\right)$ & 732.59 & 704.56 & 771.70 & 757.01 & 828.02 & 11.0 & 0.010 & 0.281 & $25+4.507 x$ \\
\hline $\operatorname{NFC}\left(g^{.} \mathrm{kg}^{-1}\right)$ & 814.36 & 823.69 & 884.34 & 873.89 & 906.00 & 6.89 & 0.001 & 0.703 & $\hat{\mathrm{Y}}=755.48+4.570 \mathrm{x}$ \\
\hline ME (Mcal.kg $\left.{ }^{-1}\right)$ & 2.7006 & 2.6464 & 2.9257 & 2.9050 & 3.1264 & 0.11 & $<.0001$ & 0.350 & $\hat{\mathrm{Y}}=2.38+0.021 \mathrm{x}$ \\
\hline
\end{tabular}

${ }^{1} 11,98=11,98 \%$ of neutral detergent fiber from Tifton hay; $18,31=18,31 \%$ of neutral detergent fiber from Tifton hay; $23,68=23,68 \%$ of neutral detergent fiber from Tifton hay; $28,76=28,76 \%$ of neutral detergent fiber from Tifton hay; $32,12=32,12 \%$ of neutral detergent fiber from Tifton hay; ${ }^{2} \mathrm{DM}=$ digestibility of dry matter; $\mathrm{NDF}=$ digestibility of neutral detergent fiber; $\mathrm{CP}=$ digestibility of crude protein; $\mathrm{EE}=$ digestibility of ether extract; NFC= digestibility of non-fiber carbohydrate; $\mathrm{ME}=$ metabolizable energy. ${ }^{3}$ Quadratic.

The time spent on ingestion was not influenced (P> 0.01) by the diet (Table 6). However, the time spent for rumination increased linearly with increasing concentrations of NDFf. There was a decreasing linear effect of the levels of NDFf on time spent on idleness, on the feeding efficiency values of DM and NDF and on the rumination efficiency of DM and NDF.

There was a linear effect of the NDFf in the diet on the production of goat milk (Table 7). The milk production of the animals consuming $11.98 \%$ NDFf in the diet was $0.15 \mathrm{~kg} /$ day less than the animals consuming $32.12 \%$ NDFf, leading to a decrease of $9 \%$ in daily milk production. The linear increase of NDFf in the diet was also observed when the milk was corrected to $4 \%$ fat. However, the decrease in milk production in the range from $32.12 \%$ to $11.98 \%$ NDFf was lower $(7 \%)$.

Table 6. Behavioral variables from dairy goats fed neutral detergent fiber from Tifton hay levels (FDNf)

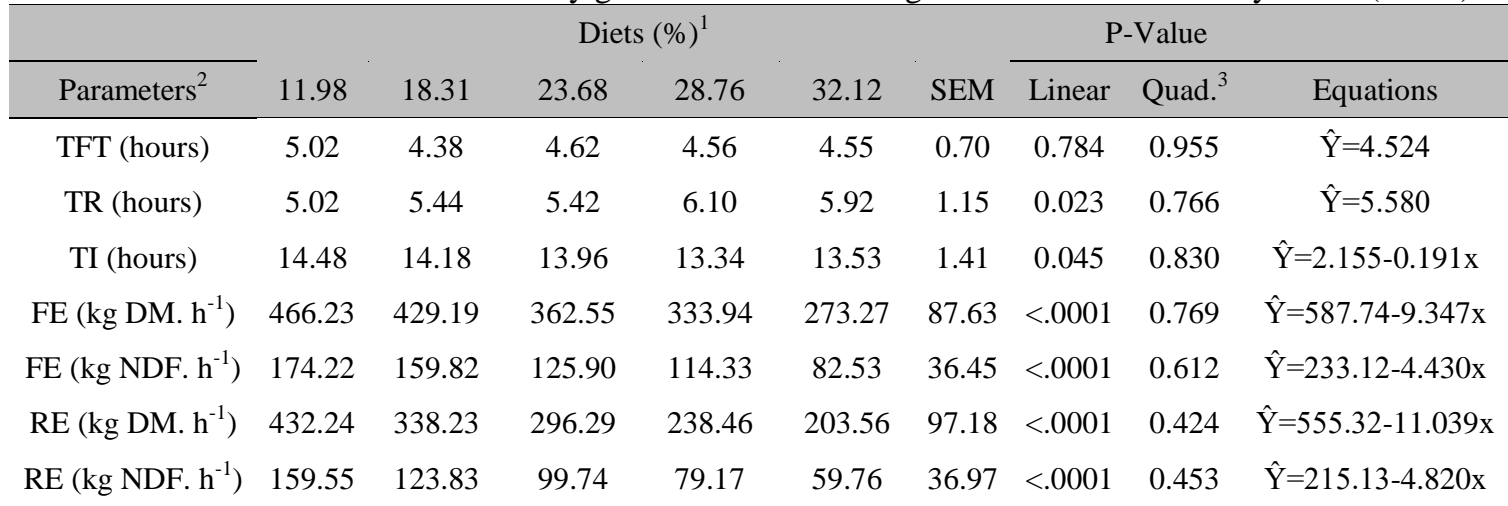

${ }^{1} 11,98=11,98 \%$ of neutral detergent fiber from Tifton hay; $18,31=18,31 \%$ of neutral detergent fiber from Tifton hay; $23,68=23,68 \%$ of neutral detergent fiber from Tifton hay; $28,76=28,76 \%$ of neutral detergent fiber from Tifton hay; $32,12=32,12 \%$ of neutral detergent fiber from Tifton hay; ${ }^{2} \mathrm{TFT}=$ total feeding time; $\mathrm{TR}=$ total rumination; $\mathrm{TI}=$ total idleness; $\mathrm{FE}=$ feeding efficiency; $\mathrm{RE}=$ rumination efficiency. ${ }^{3}$ Quadratic.

The feeding efficiency improved linearly with the increase in NDFf content in the diet (Table 7).

The chemical composition of the milk was not altered by the increase in NDFf content in the diets (Table 7) except for the milk protein concentration and $\mathrm{pH}$, which increased linearly. The total solids, fat and lactose contents showed mean values of $113.64 \mathrm{~g} / \mathrm{kg}, 38.83 \mathrm{~g} / \mathrm{kg}$ and $52.46 \mathrm{~g} / \mathrm{kg}$ of milk, respectively. 
Table 7. Milk yield and physicochemical composition of milk from dairy goats fed neutral detergent fiber from Tifton hay levels (FDNf)

\begin{tabular}{|c|c|c|c|c|c|c|c|c|c|}
\hline \multirow[b]{2}{*}{ Parameters $^{2}$} & \multicolumn{5}{|c|}{ Diets $(\%)^{1}$} & \multicolumn{3}{|c|}{ P-Value } & \multirow[t]{2}{*}{ Equations } \\
\hline & 11.98 & 18.31 & 23.68 & 28.76 & 32.12 & SEM & Linear & Quad. $^{3}$ & \\
\hline MY $\left(\right.$ Kg. day $\left.^{-1}\right)$ & 1.52 & 1.58 & 1.57 & 1.67 & 1.67 & 0.16 & 0.007 & 0.938 & $\hat{\mathrm{Y}}=1.434+0.007 \mathrm{x}$ \\
\hline FCM $4 \%\left(k g\right.$. day $\left.^{-1}\right)$ & 1.50 & 1.52 & 1.56 & 1.63 & 1.62 & 0.18 & 0.025 & 0.958 & $\hat{Y}=1.415+0.007 x$ \\
\hline $\mathrm{FE}\left(\mathrm{kg} \cdot \mathrm{kg}^{-1} \mathrm{DM}\right)$ & 0.78 & 0.93 & 1.06 & 1.20 & 1.49 & 13.50 & $<.0001$ & 0.923 & $\hat{Y}=0.348+0.032 x$ \\
\hline TS $\left(\mathrm{g} . \mathrm{kg}^{-1}\right)$ & 113.3 & 114.0 & 114.6 & 114.5 & 111.8 & 0.87 & 0.726 & 0.376 & $\hat{\mathrm{Y}}=113.64$ \\
\hline Protein $\left(\right.$ g. $\left.\mathrm{Kg}^{-1}\right)$ & 33.16 & 34.26 & 33.93 & 34.43 & 35.37 & 0.26 & 0.036 & 0.838 & $\hat{\mathrm{Y}}=3.220+0.009 \mathrm{x}$ \\
\hline Fat $\left(\mathrm{g} . \mathrm{Kg}^{-1}\right)$ & 39.58 & 37.88 & 39.76 & 38.40 & 38.54 & 0.39 & 0.629 & 0.907 & $\hat{\mathrm{Y}}=3.88$ \\
\hline Lactose $\left(\mathrm{g} . \mathrm{Kg}^{-1}\right)$ & 52.99 & 52.79 & 51.84 & 52.40 & 52.27 & 0.23 & 0.331 & 0.455 & $\hat{\mathrm{Y}}=5.25$ \\
\hline $\mathrm{pH}$ & 6.73 & 6.73 & 6.77 & 6.77 & 6.73 & 0.05 & 0.524 & 0.055 & $\hat{Y}=19.680+0.297 x$ \\
\hline Acidity ( ${ }^{\circ}$ dornic) & 14.96 & 15.01 & 14.98 & 15.15 & 14.46 & 10.64 & 0.320 & 0.224 & $\hat{\mathrm{Y}}=14.91$ \\
\hline
\end{tabular}

${ }^{\mathrm{I}} 11,98=11,98 \%$ of neutral detergent fiber from Tifton hay; $18,31=18,31 \%$ of neutral detergent fiber from Tifton hay; $23,68=23,68 \%$ of neutral detergent fiber from Tifton hay; $28,76=28,76 \%$ of neutral detergent fiber from Tifton hay; $32,12=32,12 \%$ of neutral detergent fiber from Tifton hay; ${ }^{2} \mathrm{FE}=$ Feed efficiency; MY $=$ milk yield; FCMY4\%= 4\%fat-corrected milk yield; TS= total solids. ${ }^{3}$ Quadratic.

\section{DISCUSSION}

According to Dado e Allen (1994), the consumption of rations with at least $28 \% \mathrm{NDF}$ may be limited by rumen capacity. Whereas all the rations of this experiment show NDF content higher than the value mentioned above (Table 2), the filling effect may have influenced the consumption of the rations.

The decrease in DM intake (Table 3) influenced the linear reduction in the intake of all nutrients (CP, EE, NFC, NDF) and ME. Thus, the decrease in the DM intake decreased the $\mathrm{CP}$ and $\mathrm{EE}$ intakes once the diets were formulated to be isonitrogenous and had similar levels of EE. Increasing concentrations of NDFf produced a reduction of NFC content in the ration, and with the decrease in the DM intake, there was a greater reduction of the intake of this nutrient. Despite the increase of aNDFom content with higher concentrations of NDFf, the reduction in DM intake produced a greater effect on the NDF intake. The ME comes from the sum of available energy in those nutrients; thus, as there was a decrease in the intake of them all, there was also a reduction in ME.

For dairy goats producing $2.0 \mathrm{~kg} /$ day of milk, the requirements for $\mathrm{CP}$ and TDN according to the NRC (Nutrient..., 2007) are 229.86g/day and $1219.42 \mathrm{~g} /$ day, respectively. Only the animals subjected to diets with 11.98 and $18.31 \%$ NDFf met these requirements (Table 2). This demonstrates that the filling effect had more influence on the reduction of intake than the energy concentration of the ration.

With regard to water consumption, increasing the NDFf content increased the DM content (Table 2). The DM content of the diet is one of the main factors affecting water intake (Nutrient..., 2001, 2007). This influenced the increase in water consumption in the animals that consumed higher concentrations of NDFf in the diet (Table $4)$.

However, in semi-arid regions, a limited water supply can be an obstacle to livestock production. Thus, the lower intake of supplied water by the animals that receive lower NDFf concentrations in the diet can be beneficial (Oliveira et al., 2007).

The increased digestibility of NDF of rations with higher fiber content was also observed by Kendall et al. (2009) in dairy cows. Branco et al. (2011), working with dairy goats, found a decrease in the digestibility of $\mathrm{DM}, \mathrm{OM}$, and NFC when the NDFf content was increased in the diet. However, Branco et al. (2011) worked with higher levels of NDFf in the diet compared to this study.

The excess of NFC in diets for ruminants can also cause metabolic diseases (Nutrient..., 2001). Diets with high concentration of forage palm, as observed in this work, has high concentrations of 
NFC (Table 2). Thus, the presence of NDF improves digestion and animal health.

The increasing linear effect of the digestibility of DM, CP, NDF, EE, NFC and ME (Table 5) when increasing the concentration of NDFf in the diet may be due to lower DM intake and to the longer retention time of fiber in the rumen. This allowed the nutrients to stay in the rumen for a longer period to be fermented by ruminal microorganisms, which consequently allowed additional nutrients to be absorbed in the gastrointestinal tract. Kendall et al. (2009) observed through markers that the outflow rate of cows decreased when NDF content was increased from $28 \%$ to $32 \%$ in the diet.

The retention time of fiber in the rumen is related to the time required to reduce the size of the food particles by rumination, so that they can pass through the reticulo-omasal orifice. Forage fiber is one of the components that stimulate rumination (Krause et al., 2002). Table 6 demonstrates that increasing the NDFf content in the diet increased the rumination time. Tavares et al. (2005) also observed this behavior in goats.

The sum of the lower DM and NDF intakes and longer rumination time when increasing the NDFf content in the rations probably caused the feeding and rumination efficiency of both DM and NDF to decrease (Table 6). The values observed in this experiment behaved similarly to Branco et al. (2011) and Carvalho et al. (2006).

The MY, FCM4\% and FE of the goats increased linearly with the increasing concentration of NDFf in the diets with forage palm (Table 7), even with the decrease in nutrient intake. There was also an increase in rumination activity with the increase in NDFf content and, consequently, in chewing. NDF increases chewing activity, which increases salivary secretion, preventing the decline of ruminal $\mathrm{pH}$ (Yang e Beauchemin, 2005).

Bispo et al. (2007) observed that the use of forage palm replacing elephant grass hay in the sheep diet changed ruminal $\mathrm{pH}$. Animals fed a non-palm diet had an average $\mathrm{pH}$ of 6.46 while in diet with $56 \%$ of forage palm the $\mathrm{pH}$ decreased to 6.24. A drop in ruminal $\mathrm{pH}$ changes the microbial population, reducing the digestibility of nutrients (Véras et al., 2000). The behavior of the digestibility of nutrients observed in this study (Table 5) demonstrates this.

This lower digestibility when there are lower concentrations of NDFf in the diet is probably due to a disadvantage of rumen function and digestion of fiber, worsening the energy and protein ratio and decreasing microbial protein synthesis in the rumen (Yang e Beauchemin, 2005). On the other hand, the high ruminal degradability maximizes the fermentation capacity of the rumen, thus increasing microbial protein synthesis, the production of volatile fatty acids and, as a consequence, the conduction of nutrients to the animal (Ferreira et al., 2010).

The higher microbial protein synthesis in the rumen may have also increased the amount of digestible intestinal protein which was used by the animal for milk protein synthesis. This may have been reflected in the higher production and protein content in the milk when the concentration of NDFf was increased in the diet (Table 7).

Besides, the current study the NFC of the diets with $11.98 \%$ and $18.31 \%$ of NDFf content exceeded maximum recommendation $(44 \%$ of NFC). Diets with excess of NFC cause depression milk production as a result ruminal upsets and health problems (Nutrient..., 2001). However, even when the NDFf concentration was lower in the diet, all tested levels provided protein values recommended by the current legislation in Brazil (IN 37), which is at least $2.8 \%$ in the milk (Brasil, 2000).

Likewise, the concentrations of total solids, lactose, fat, acidity and $\mathrm{pH}$ of the milk maintained values that met current regulations (Brasil, 2000), regardless of the concentration of NDFf in the diet of the animals (Table 7).

Branco, et al. (2011) suggested that 35\% NDF from forage is the concentration at which the best efficiency in the use of forage in rations for dairy goats is obtained; beyond this point, milk production reaches a plateau. In this study, all the rations presented NDFf content lower than 35\%. This range explains the increasing linear effect on milk production when the concentration of NDFf increased in the diet. 
According to the NRC (Nutrient..., 2001), diets with less than $250 \mathrm{~g}$ NDF. $\mathrm{Kg}^{-1} \mathrm{DM}$ and $190 \mathrm{~g}$ NDFf. $\mathrm{Kg}^{-1} \mathrm{DM}$ depress the percentage of fat in cow's milk. In balancing goat rations, the NRC (Nutrient..., 2007) also uses these studies to recommend the minimum amount of NDF in the ration.

In the studied range from $11.98 \%$ to $32.12 \%$ NDFf, all the diets were able to maintain the percentage of fat in milk (Table 7), indicating that the recommendations of NRC (Nutrient..., 2007) and NRC (Nutrient..., 2001) do not apply to dairy goats fed forage palm.

Goats have anatomical and physiological variations that differentiate them from bovines. Goats have bigger salivary glands, a smaller rumen in relation to body weight, and anatomy for grasping food that favors the selection of more digestible food (Van Soest, 1994). Furthermore, goats have a faster outflow rate in the gastrointestinal tract than bovines (Van Soest, 1994). These differences can make goats more tolerant to use diets with low content of effective fiber and high concentrations of NFC.

In arid and semi-arid regions, during drought periods, one of the major restraints to livestock production is the amount of forage available other than palm. Using fodder in concentrations lower than those recommended by the NRC (Nutrient..., 2007) can favor milk production at this time of year, as it would allow more inclusion of palm in the formulation of the ration. The use of minimal amounts of NDFf could help the farmer to keep the flock with lower production, while maintaining the quality of the goat milk, when adequate quantities of forage are not available on the property.

\section{CONCLUSION}

In situations where dairy goats are fed forage palm and other types of forage are limited, $11.98 \%$ neutral detergent fiber from forage other than palm can be used as an effective source of neutral detergent fiber.

\section{ACKNOWLEDGMENTS}

Thanks to the National Council for Scientific and Technological Development (CNPq), who funded this research.

\section{REFERENCES}

BATISTA, Â.M.; RIBEIRO NETO, A.C.; LUCENA, R.B. et al. Chemical composition and ruminal degradability of spineless cactus grown in Northeastern Brazil. Rangeland Ecol. Management, v.62, p.297-301, 2009.

BERCHIELLI, T.T.; VEGA-GARCIA, A.; OLIVEIRA, S.G. Principais técnicas de avaliaçäo aplicadas em estudo de nutrição. In: BERCHIELLI, T.T. Nutriçäo de ruminantes. 2.ed. Jaboticabal: Funep, 2011. p.415-436.

BISPO, S.V.; FERREIRA, M.D.A.; VÉRAS, A.S.C. et al. Palma forrageira em substituição ao feno de capim-elefante. Efeito sobre consumo, digestibilidade e características de fermentação ruminal em ovinos. Rev. Bras. Zootec. v.36, p.1902-1909, 2007.

BRANCO, R.H.; RODRIGUES, M.T.; SILVA, M.M.C. et al. Desempenho de cabras em lactação alimentadas com dietas com diferentes níveis de fibra oriundas de forragem com maturidade avançada. Rev. Bras. Zootec. v.40, p.1061-1071. 2011.

BRASIL. Ministério da Agricultura e do Abastecimento. Secretaria Nacional de Defesa Agropecuária. Instrução Normativa no 37 , de 31 de outubro de 2000. Regulamento técnico de produção, identidade e qualidade do leite de cabra. Diário Oficial da União, Brasília, 8 nov. de 2000.

BÜRGER, P.J.; PEREIRA, J.C.; QUEIROZ, A.C. et al. Comportamento ingestivo em bezerros holandeses alimentados com dietas contendo diferentes níveis de concentrado. Rev. Bras. Zootec. v.29, p.236-242, 2000.

CARVALHO, S.; RODRIGUES, M.T.; BRANCO, R.H. et al. Comportamento ingestivo de cabras alpinas em lactação alimentadas com dietas contendo diferentes níveis de fibra em detergente neutro proveniente de forragem. Rev. Bras. Zootec., v.35, p.562-568, 2006.

CASALI, A.O. Procedimentos metodológicos in situ na avaliação dos compostos indigestíveis em alimentos e fezes de bovinos. 2006. 58f. Dissertação (Mestrado em Zootecnia.). Universidade Federal de Viçosa, Viçosa, MG. 
DADO, R.G.; ALLEN, M.S. Intake limitations, feeding behavior, and rumen function of cows challenged with rumen fill from dietary fiber or inert bulk. J. Dairy Sci., v.78, p.118-133,1994.

FERREIRA, M.A.; PESSOA, R.A.; BISPO, S.V. Otimização de dietas a base de palma forrageira e outras alternativas de suplementação para regiões semi-áridas. In: SIMPÓSIO DE PRODUÇÃO DE GADO DE CORTE, 7., 2010, Viçosa. Anais... Viçosa: [UFV], 2010. p.242.

JOHNSON, T.R.; COMBS, D.K. Effects of prepartum diet, inert rumen bulk, and dietary polyethylene glycol on dry matter intake of lactating dairy cows. J. Dairy Sci., v.74, p.933944, 1991.

KENDALL, C.; LEONARDI, C.; HOFFMAN, P.C.; COMBS, D.K. Intake and milk production of cows fed diets that differed in dietary neutral detergent fiber and neutral detergent fiber digestibility. J. Dairy Sci., v.92, p.313-323, 2009.

KRAUSE, K.M.; COMBS, D.K.; BEAUCHEMIN, K.A. Effects of forage particle size and grain fermentability in midlactation cows. II. Ruminal $\mathrm{pH}$ and chewing activity. $J$. Dairy Sci., v.85, p.1947-1957, 2002.

LICITRA, G.; HERNANDEZ, T.M.; VAN SOEST, P.J. Standardization of procedures for nitrogen fractionation of ruminant feeds. Anim. Feed Sci. Tech., v.57, p.347-358, 1996.

MARTIN, P.; BATESON, P. Measuring behavior and introductory guide. 3.ed. New York: Cambridge University Press, 1986. 176p.

MERTENS, D.R. Creating a system for meeting the fiber requirements of dairy cows. J. Anim. Sci. v.80, p.1463-1481, 1997.

MERTENS, D.R. Gravimetric determination of amylase-treated neutral detergent fiber in feeds with refluxing in beakers or crucibles: collaborative study. J. AOAC Int., v.85, p.12171240, 2002.

MÉTODOS físico-químicos para análise de alimentos. 4. ed. Brasília: Ministério da Saúde, Agência Nacional de Vigilância Sanitária / Instituto Adolfo Lutz, 2005. p.819-877. (Série A - Normas e Manuais Técnicos)
NUTRIENT requeriments of dairy cattle. 2.ed. Washington: National Academy of Science, 2001. 333p.

NUTRIENT requeriments of small ruminants. Washington: National Academy of Science, 2007. 292p.

OFFICIAL methods of analysis. 16.ed. Arlington: AOAC International, 1998.

OLIVEIRA, V.S.; FERREIRA, M.A.; GUIM, A.; MODESTO, E.C. et al. Forrageira em dietas para vacas em lactação. Substituição total do milho e parcial do feno de capim-tifton por palma. Consumo e digestibilidade. Rev. Bras. Zootec., v.36, p.1419-1425, 2007.

SAS. Statistical analysis system. Version. Cary: SAS Institute, 2017.

SNIFFEN, C.J.; O'CONNOR, J.D.; VAN SOEST, P.J. et al. A net carbohydrate and protein system for evaluating cattle diets: 2 . Carbohydrate and protein availability. J. Anim. Sci., v.70, p.3562-3577, 1992.

TAVARES, A.M.A.; VÉRAS, A.S.C.; BATISTA, A.M.V. et al. Níveis crescentes de feno em dietas à base de palma forrageira para caprinos em confinamento: comportamento ingestivo. Acta Sci. Anim. Sci., v.27, p.497-504, 2005.

VAN SOEST, P.J. Nutritional ecology of the ruminant. 2.ed. Ithaca: Cornell University Press, 1994. 476p.

VÉRAS, A.S.C.; VALADARES FILHO, S.C.; SILVA, J.F.C. Consumo e digestibilidade aparente em bovinos nelore, não castrados, alimentados com rações contendo diferentes níveis de concentrado. Rev. Bras. Zootec., v.29, p.2367-2378, 2000 .

WANDERLEY, W.L.; FERREIRA, M.A.; ANDRADE, D.K.B. Palma forrageira (Opuntia ficus indica, Mill) em substituição à silagem de sorgo (Sorghum bicolor (L.) na alimentação de vacas leiteiras. Rev. Bras. Zootec., v.31, p.273$281,2002$.

YANG, W.Z.; BEAUCHEMIN, K.A. Effects of physically effective fiber on digestion and milk production by dairy cows fed diets based on corn silage. J. Dairy Sci., v.88, p.1090-1098, 2005. 